\title{
PENGARUH PENERAPAN STRATEGI OPEN ENDED PROBLEM BERSETTING KOOPERATIF TERHADAP KEMAMPUAN MENYELESAIKAN MASALAH DITINJAU DARI KREATIVITAS SISWA SMP PGRI 6 MALANG
}

\author{
Hena Dian Ayu ${ }^{1)}$ Akhmad Jufriadi ${ }^{2)}$ \\ Prodi Pendidikan Fisika FKIP Universitas Kanjuruhan Malang \\ email: henadian@gmail.com \\ akhmadjufriadi@unikama.com
}

\begin{abstract}
Abstrak: Pembelajaran open ended problem bersetting kooperatif merupakan pembelajaran dimana guru menyajikan permasalahan dengan banyak jawaban, kemudian siswa mendiskusikannya dalam kelompok belajar dan mempresentasikan hasil diskusi serta pada akhirnya guru menyimpulkan hasil diskusi siswa mengenai materi yang didapatkan siswa. Sedangkan kreativitas adalah kemampuan untuk menemukan sesuatu yang baru dan merupakan kombinasi berpikir logis dan berpikir divergen yang memperhatikan fleksibilitas, kefasihan, dan kebaruan dalam memecahkan maupun mengajukan masalah. Tujuan dari penelitian ini adalah mengetahui efektivitas strategi open ended problem bersetting kooperatif terhadap kemampuan menyelesaikan masalah ditinjau dari kreativitas siswa. Rancangan yang digunakan dalam penelitian ini adalah quasi experiment dengan desain faktorial $2 \times 2$. Populasi penelitian adalah siswa Kelas VII SMP PGRI 6 Malang, dan sampelnya adalah 1 kelas eksperimen dan 1 kelas kontrol. Teknik untuk menguji hipotesis adalah dengan mengunakan uji ANAVA dua jalur. Hasil penelitian menunjukkan bahwa: 1) kemampuan penyelesaian masalah fisika siswa yang belajar dengan strategi open ended problem bersetting kooperatif lebih tinggi dibandingkan dengan pembelajaran konvensional, 2) Terdapat interaksi antara strategi open ended problem bersetting kooperatif dengan kreativitas terhadap kemampuan penyelesaian masalah fisika, 3) Kemampuan penyelesaian masalah siswa dengan kreativitas tinggi, yang belajar dengan strategi open ended problem bersetting kooperatif lebih tinggi daripada dengan pembelajaran konvensional, 4) Kemampuan penyelesaian masalah fisika siswa dengan kreativitas rendah yang belajar dengan strategi open ended problem bersetting kooperatif lebih rendah daripada pembelajaran konvensional.
\end{abstract}

Kata kunci: kreativitas, kemampuan menyelesaikan masalah, open ended problem

\begin{abstract}
Learning of open ended problems set in cooperative is learning where the teacher presents a problem that has many answers, then the students discuss in the group study and presented the results of discussions and ultimately the teacher concludes the discussion of students in the subject matter or concept of what the student obtained. Creativity is the ability to prepare or find something new and combination of logical thinking and divergent thinking that takes into account the flexibility, fluency, and novelty in solving problems and pose problems. The aim of this research was to determine the effectiveness of the open ended problems strategy set in cooperatively in the ability to solve the problem in terms of the creativity of the students. The design used in this research is a quasi experiment with a $2 \times 2$ factorial design. The research population are students of seventh grade in junior high school at PGRI 6 Malang, and the research sample is first grade as a experiment class that we apply the open ended problems strategy set in cooperatively and one class as control class that implements learning the Conventional methods. The techniques that we use to test the hypothesis is ANOVA. The results from this research showed that: 1) the ability of solving physics students that use the open ended problems strategy set in cooperative higher than use conventional learning, 2) There is interaction between the open ended problems strategy set in cooperation with the creativity of the ability of problem solving physics, 3)The ability solving problems of students with high creativity that use the open ended problems strategy set in cooperative higher than use conventional learning, 4)The ability solving problems of students with low creativity, that use the open ended problems strategy set in cooperative lower than use conventional learning.
\end{abstract}

Keywords: creativity, ability to solve the problem, open ended problems

\section{PENDAHULUAN}

Pembelajaran fisika adalah pembelajaran yang tidak mengabaikan hakikat fisika sebagai sains.
Hakikat sains yang dimaksud meliputi produk, proses, dan sikap ilmiah. Pembelajaran fisika seharusnya dapat memberikan pengalaman 
langsung pada siswa sehingga menambah kemampuan dalam mengkonstruksi, memahami, dan menerapkan konsep yang telah dipelajari. Dengan demikian, siswa akan terlatih menemukan sendiri berbagai konsep secara holistik, bermakna, otentik serta aplikatif untuk kepentingan pemecahan masalah [1]. Kurangnya interaksi antara guru dan siswa serta komunikasi yang terjadi antara guru dan siswa masih satu arah atau bisa dikatakan bahwa pembelajaran masih berorientasi pada guru (teacher center), sedangkan siswa hanya bekerja secara prosedural. Hal ini menjadikan siswa tidak bisa memahami konsep dengan baik untuk bisa menyelesaikan permasalahan yang ada [7]. Menurut Vygotsky mengajar adalah aktivitas sosial bersama. Pemberian tugas kepada peserta didik yang tidak dapat diselesaikan sendiri hendaknya didampingi oleh orang dewasa atau teman sebaya yang lebih mampu. Tugas-tugas dalam zona ini belum dipelajari oleh Siswa tetapi dapat dipelajari jika diberi waktu yang sesuai selain itu fungsi mental yang tinggi dapat terjadi melalui percakapan dan kolaborasi. Menurut Moll semua hal tersebut dapat tercapai dalam pembelajaran kooperatif [5]. Umumnya pembelajaran yang terjadi di sekolah juga kurang memperhatikan bagaimana meningkatkan kreativitas siswa dan hanya terpaku pada bagaimana meningkatkan pemahaman siswa. Padahal kreativitas dikatakan penting dalam hidup karena dengan berkreasi orang dapat mewujudkan dirinya, dan perwujudan diri termasuk salah satu kebutuhan pokok dalam hidup mandiri [6]. Kreativitas adalah kemampuan untuk menciptakan atau menemukan sesuatu yang baru dan berpikir kreatif dalam fisika merupakan kombinasi berfikir logis dan berpikir divergen yang memperhatikan fleksibilitas, kelancaran, dan kebaruan dalam memecahkan maupun mengajukan masalah [12]. Dan untuk mengungkapkan atau menjaring manusia kreatif itu sebaiknya kita menggunakan pertanyaan-pertanyaan terbuka (divergen), pertanyaan yang jawabannya bisa lebih dari satu dan tidak bisa diperkirakan dari sebelumnya [13].

Menggunakan masalah terbuka dapat memberi siswa banyak sumber pengalaman dalam menafsirkan masalah, dan mungkin pembangkitan solusi berbeda dihubungkan dengan penafsiran yang berbeda. Siswa tidak hanya dapat menjadi mampu dalam menemukan dan menyelesaikan masalah dari sebuah situasi, tetapi mereka dapat juga mengembangkan fleksibilitas dengan kemampuan mereka menemukan banyak solusi pada sebuah masalah. Melalui cara ini siswa juga dapat dikembangkan untuk dapat memecahan permasalahan yang baru. Kemampuan berpikir kreatif dapat diukur dengan fleksibilitas, kebaruan, dan kelancaran. Fleksibilitas yaitu kemampuan siswa dalam memecahkan permasalahan fisika dengan berbagai cara yang berbeda. Kebaruan yaitu kemampuan siswa dalam membuat berbagai jawaban yang berbeda dan benar dalam memecahkan permasalahan. Jawaban yang berbeda yaitu jawaban-jawaban yang diperoleh tidak sama dan tidak membentuk suatu pola tertentu. Kelancaran yaitu kemampuan siswa dalam membuat jawaban yang beragam dan benar dalam memecahkan masalah. Jawaban yang beragam yaitu jawaban yang diperoleh tidak sama dan membentuk pola tertentu [11].

Berdasarkan beberapa permasalahan dalam pembelajaran mengenai kurangnya perhatian guru terhadap pentingnya meningkatkan aspek kreativitas pada siswa dan kemampuan siswa dalam memecahkan masalah fisika maka diperlukan beberapa solusi untuk mengatasinya. Salah satu solusi efektif adalah pembelajaran dengan strategi open ended problem bersetting kooperatif. Strategi open ended problem adalah salah satu strategi pembelajaran yang menyajikan suatu metode atau penyelesaian yang benar lebih dari satu, sehingga dapat memberi kesempatan kepada 
siswa untuk memperoleh pengetahuan atau pengalaman menemukan, mengenali, dan memecahkan masalah dengan beberapa tehnik [10]. Dimana dalam pelaksanaannya berpijak pada 5 komponen model pembelajaran yaitu, (1) sintaks, (2) sistem sosial, (3) prinsip reaksi, (4) sistem pendukung, dan (5) dampak instruksional dan pengiring. Sintaks pada pembelajaran ini terdiri dari 6 fase yaitu, (1) orientasi, (2) pembekalan dan penyajian masalah, (3) pengerjaan masalah secara individu, (4) diskusi kelompok, (5) presentasi, dan (6) penutup [3]. Keleluasaan berpikir melalui strategi open ended problem bersetting kooperatif membawa Siswa untuk lebih memahami suatu konsep fisika dan keterikatannya dengan konsep lainnya, baik dalam pelajaran lainnya, dan dalam kehidupan sehari-hari [8] .

\section{METODE PENELITIAN}

Jenis penelitian ini adalah quasi experiment design dengan desain faktorial $2 \times 2$, sebagaimana tampak pada tabel 1. Populasi pada penelitian ini adalah kelas VII SMP PGRI 6 Malang. Selanjutnya dengan teknik purposive sampling ditetapkan 1 kelas sebagai kelompok eksperimen dan 1 kelas sebagai kelompok kontrol. Instrumen penelitian terdiri atas instrumen perlakuan dan instrumen pengukuran. Instrumen perlakuan terdiri atas RPP dan LKS. Instrumen pengukuran terdiri atas instrumen tes kreativitas dan tes kemampuan penyelesaian masalah fisika. Sebelum digunakan instrumen tersebut terlebih dahulu divalidasi isinya secara empirik.

Tabel 1. Desain Penelitian

\begin{tabular}{ccc}
\hline & \multicolumn{2}{c}{ Model Pembelajaran (A) } \\
\cline { 2 - 3 } $\begin{array}{c}\text { Tingkat } \\
\text { Kreativitas } \\
(\mathbf{B})\end{array}$ & $\begin{array}{c}\text { strategi open } \\
\text { ended problem } \\
\text { bersetting } \\
\text { kooperatif }\end{array}$ & Konvensional \\
\cline { 2 - 3 }$\left(\mathrm{A}_{1}\right)$ & $\left(\mathrm{A}_{2}\right)$ \\
\hline Tingkat & & \\
Kreativitas & $\mathbf{A}_{\mathbf{1}} \mathbf{B}_{1}$ & $\mathbf{A}_{\mathbf{2}} \mathbf{B}_{\mathbf{1}}$ \\
Tinggi $\left(\mathrm{B}_{1}\right)$ & & \\
\hline
\end{tabular}

\begin{tabular}{ccc}
\hline Tingkat & & \\
Kreativitas & $\mathbf{A}_{\mathbf{1}} \mathbf{B}_{\mathbf{2}}$ & $\mathbf{A}_{\mathbf{2}} \mathbf{B}_{\mathbf{2}}$ \\
Rendah $\left(\mathrm{B}_{2}\right)$ & & \\
\hline
\end{tabular}

Keterangan:

$\mathrm{A}_{1} \mathrm{~B}_{1}$ :Kemampuan penyelesaian masalah fisika siswa pada pembelajaran dengan strategi open ended problem bersetting kooperatif dengan tingkat kreativitas tinggi.

$\mathrm{A}_{1} \mathrm{~B}_{2}$ :Kemampuan penyelesaian masalah fisika siswa pada pembelajaran dengan strategi open ended problem bersetting kooperatif dengan tingkat kreativitas rendah.

$\mathrm{A}_{2} \mathrm{~B}_{1}$ :Kemampuan penyelesaian masalah fisika siswa pada pembelajaran konvensional dengan tingkat kreativitas tinggi.

$\mathrm{A}_{2} \mathrm{~B}_{2}$ :Kemampuan penyelesaian masalah fisika siswa pada pembelajaran konvensional dengan tingkat kreativitas rendah.

Data tingkat kreativitas siswa diperoleh sebelum perlakuan, tetapi untuk mengetahui peningkatan kreativitas siswa data kreativitas juga diambil setelah perlakuan. Data tingkat kreativitas siswa yang diperoleh sebelum perlakuan digunakan untuk mengelompokkan siswa pada tingkat kreativitas tinggi dan tingkat kreativitas rendah. Sedangkan data kemampuan penyelesaian masalah fisika diperoleh setelah perlakuan. Uji prasyarat normalitas dan homogenitas dilakukan pada data tingkat kreativitas siswa dan kemampuan penyelesaian masalah fisika. Uji normalitas menggunakan uji lilliefors dan uji homogenitas menggunakan uji bartlett. Uji hipotesis penelitian menggunakan uji beda dengan ANAVA dua jalur dan dilanjutkan dengan uji Scheffe untuk mengetahui efektifitas pembelajaran dengan strategi open ended problem bersetting kooperatif terhadap kemampuan penyelesaian masalah fisika ditinjau dari kreativitas.

\section{HASIL DAN PEMBAHASAN}

Berdasarkan tujuan penelitian, terdapat beberapa temuan hasil penelitan. Hasil penelitian yang diperoleh adalah data tingkat kreativitas siswa 
JIP, Vol.7, No. 1, Edisi Januari 2017, Hal: 1-6 Hena Dian Ayu, Akhmad Jufriadi

dan kemampuan penyelesaian masalah Fisika yang dapat dilihat pada tabel 2, 3 dan tabel 4 .

Tabel 2. Data Tingkat Kreativitas

\begin{tabular}{|c|c|c|c|c|}
\hline $\begin{array}{c}\text { Kelompok } \\
\text { Kelas }\end{array}$ & $\begin{array}{c}\text { Jumlah } \\
\text { Data } \\
\text { (N) }\end{array}$ & $\begin{array}{l}\text { Rata- } \\
\text { Rata }\end{array}$ & $\begin{array}{c}\text { Skor } \\
\text { Terting } \\
\text { gi }\end{array}$ & $\begin{array}{c}\text { Skor } \\
\text { Terend } \\
\text { ah }\end{array}$ \\
\hline $\begin{array}{c}\text { Open Ended } \\
\text { Problem } \\
\text { Bersetting } \\
\text { Kooperatif }\end{array}$ & 65 & $\begin{array}{c}28,82 \\
3\end{array}$ & 36 & 32 \\
\hline Konvensional & 63 & $\begin{array}{c}21,25 \\
4\end{array}$ & 35 & 28 \\
\hline
\end{tabular}

Tabel 3. Skor Tingkat Kreativitas Tinggi dan rendah

\begin{tabular}{|c|c|c|c|c|c|}
\hline \multicolumn{2}{|c|}{ Kelompok Kelas } & $\begin{array}{c}\text { Jumlah } \\
\text { Data }(\mathrm{N})\end{array}$ & $\begin{array}{l}\text { Rata- } \\
\text { Rata }\end{array}$ & $\begin{array}{l}\text { Skor } \\
\text { Tertin } \\
\text { ggi }\end{array}$ & $\begin{array}{c}\text { Skor } \\
\text { Teren } \\
\text { dah }\end{array}$ \\
\hline \multirow{2}{*}{$\begin{array}{c}\text { Open } \\
\text { Ended } \\
\text { Problem } \\
\text { Bersetting } \\
\text { Kooperatif }\end{array}$} & $\begin{array}{c}\text { Kreativitas } \\
\text { Tinggi }\end{array}$ & 21 & $\begin{array}{c}35,0 \\
62\end{array}$ & 36 & 28 \\
\hline & $\begin{array}{c}\text { Kreativitas } \\
\text { rendah }\end{array}$ & 21 & $\begin{array}{c}32,7 \\
21\end{array}$ & 33 & 32 \\
\hline \multirow{2}{*}{$\begin{array}{c}\text { Konvension } \\
\text { al }\end{array}$} & $\begin{array}{c}\text { Kreativitas } \\
\text { Tinggi }\end{array}$ & 21 & $\begin{array}{c}33,8 \\
31\end{array}$ & 35 & 24 \\
\hline & $\begin{array}{c}\text { Kreativitas } \\
\text { rendah }\end{array}$ & 21 & $\begin{array}{c}28,9 \\
82\end{array}$ & 30 & 28 \\
\hline
\end{tabular}

Tabel 4. Deskripsi Skor Kemampuan Penyelesaian Masalah Fisika

\begin{tabular}{cccccc}
\hline Kelompok Kelas & $\begin{array}{c}\text { Jumlah } \\
\text { Data (N) }\end{array}$ & $\begin{array}{c}\text { Rata } \\
\text { Rata }\end{array}$ & $\begin{array}{c}\text { Skor } \\
\text { Tertin } \\
\text { ggi }\end{array}$ & $\begin{array}{c}\text { Skor } \\
\text { dah }\end{array}$ \\
\hline $\begin{array}{c}\text { Open } \\
\text { Ended } \\
\text { Problem } \\
\text { Bersetting } \\
\text { Kooperatif }\end{array}$ & $\begin{array}{c}\text { Kreativitas } \\
\text { Tinggi }\end{array}$ & 21 & 72,062 & 76 & 72 \\
\cline { 2 - 6 } & $\begin{array}{c}\text { Kreativitas } \\
\text { rendah }\end{array}$ & 21 & 62,721 & 67 & 52 \\
\hline $\begin{array}{c}\text { Konvension } \\
\text { al }\end{array}$ & $\begin{array}{c}\text { Kreativitas } \\
\text { Tinggi }\end{array}$ & 21 & 66,831 & 69 & 65 \\
\hline $\begin{array}{c}\text { Kreativitas } \\
\text { rendah }\end{array}$ & 21 & 56,982 & 59 & 48 \\
\hline
\end{tabular}

Tabel 5. Hasil Uji ANAVA Dua Jalur

\begin{tabular}{cccc}
\hline \multirow{2}{*}{ Sumber Varian } & \multicolumn{2}{c}{$\mathrm{F}(\alpha=0,05)$} & Keterangan \\
\cline { 2 - 3 } & $\mathrm{F}_{\text {hitung }}$ & $\mathrm{F}_{\text {tabel }}$ & \\
\hline $\begin{array}{c}\text { Model Pembelajaran } \\
\text { (A) }\end{array}$ & 46,59 & 3,92 & Berbeda \\
\hline $\begin{array}{c}\text { Tingkat Kreativitas } \\
\text { (B) }\end{array}$ & 48,986 & 3,92 & Berbeda \\
\hline
\end{tabular}

\begin{tabular}{cccc}
\hline Interaksi (A x B) & 10,5 & 3,92 & $\begin{array}{c}\text { Ada } \\
\text { Interaksi }\end{array}$ \\
\hline
\end{tabular}

Tabel 6. Hasil Uji Beda Kemampuan Penyelesaian Masalah Fisika Siswa Kelompok Kreativitas Tinggi

\begin{tabular}{cccc}
\hline \multirow{2}{*}{ Sumber Varian } & \multicolumn{2}{c}{$\mathrm{F}(\alpha=0,05)$} & \multirow{2}{*}{ Keterangan } \\
\cline { 2 - 3 } & $\mathrm{F}_{\text {hitung }}$ & $\mathrm{F}_{\text {tabel }}$ & \\
\hline Antar A & 107,6 & 4,02 & Diterima \\
\hline
\end{tabular}

Tabel 7. Hasil Uji Beda Kemampuan Penyelesaian Masalah Fisika Siswa Kelompok Kreativitas Rendah

\begin{tabular}{cccc}
\hline \multirow{2}{*}{ Sumber Varian } & \multicolumn{2}{c}{$\mathrm{F}(\alpha=0,05)$} & \multirow{2}{*}{ Keterangan } \\
\cline { 2 - 3 } & $\mathrm{F}_{\text {hitung }}$ & $\mathrm{F}_{\text {tabel }}$ & \\
\hline Antar $\mathrm{A}$ & 178,69 & 4,05 & Diterima \\
\hline \multicolumn{2}{c}{ Tabel 8. Hasil Uji Scheffe } & \\
\hline \multirow{2}{*}{ Sumber Varian } & $\mathrm{F}(\alpha=0,05)$ & \multirow{2}{*}{ Keterangan } \\
\cline { 2 - 3 } & $\mathrm{F}_{\text {hitung }}$ & $\mathrm{F}_{\text {tabel }}$ & \\
\hline $\mathrm{A}_{1}$ dan $\mathrm{A}_{2}$ & 7,56 & 2,68 & Diterima \\
\hline $\mathrm{A}_{1}$ dan $\mathrm{A}_{2}$ untuk $\mathrm{B}_{1}$ & 17,24 & 2,76 & Diterima \\
\hline $\mathrm{A}_{1}$ dan $\mathrm{A}_{2}$ untuk $\mathrm{B}_{2}$ & 5,31 & 2,78 & Ditolak \\
\hline
\end{tabular}

Hasil penelitian terkait uji hipotesis menggunakan ANAVA dua jalur dan uji Scheffe, dapat dilihat pada tabel 5, 6, 7 dan tabel 8.

Uji hipotesis dilakukan setelah melakukan uji prasyarat normalitas dan homogenitas terdahadap data tingkat kreativitas dan kemampuan menyelesaikan masalah fisika. Berdasarkan hasil uji prasyarat diperoleh bahwa data tingkat kreativitas untuk keseluruhan kelompok terdistribusi normal dan memiliki varian yang homogen.

Pengujian hipotesis diawali dengan uji beda ANAVA dua jalur terhadap data kemampuan penyelesaian masalah fisika yang tampak pada tabel 5. Hipotesis diterima apabila nilai $F_{\text {hitung }}>F_{\text {tabel }}$ pada taraf signifikansi 0,05. Hasil uji beda ANAVA siswa dengan tingkat kreativitas tinggi terhadap kemampuan menyelesaikan masalah fisika tampak pada tabel 6 .

Hasil uji beda ANAVA siswa dengan tingkat kreativitas rendah terhadap kemampuan penyelesaian masalah fisika disajikan pada tabel 
7. Setelah dilakukan uji beda, pengujian hipotesis dilakukan dengan uji Scheffe untuk menguji efektifitas pembelajaran dengan strategi open ended problem bersetting kooperatif terhadap kemampuan menyelesaikan masalah fisika. Hasil uji Scheffe disajikan pada tabel 8.

Hasil uji beda ANAVA siswa dengan tingkat kreativitas tinggi terhadap kemampuan menyelesaikan masalah fisika tampak pada tabel 6 , diperoleh nilai $F_{\text {hitung }}>F_{\text {tabel }}$ yaitu 107,6 > 4,02 sehingga disimpul-kan terdapat perbedaan kemampuan penyelesaian masalah fisika siswa yang belajar dengan strategi open ended bersetting kooperatif dan kelas kon-vensional. Hasil uji lanjutan sebagaimana yang tampak pada tabel 8, menunjukkan bahwa nilai $\mathrm{F}_{\text {hitung }}>$ $F_{\text {tabel }}$ yaitu $7,56>2,68$ sehingga dapat disimpulkan bahwa kemampuan penyelesaian masalah fisika pada siswa yang belajar dengan strategi open ended bersetting kooperatif lebih tinggi dibandingkan dengan yang belajar dengan metode konvensional.

Berdasarkan apa yang tampak pada tabel 5 terlihat bahwa $\mathrm{F}_{\text {hitung }}>\mathrm{F}_{\text {tabel }}$ yaitu 10,5 $>3,92$ sehingga dapat disimpulkan terdapat interaksi antara pembelajaran dengan strategi open ended bersetting kooperatif dengan tingkat kreativitas terhadap kemampuan menyelesaikan masalah fisika.

Pada tabel 5 dapat dilihat bahwa $\mathrm{F}_{\text {hitung }}>\mathrm{F}_{\text {tabel }}$ yaitu 48,986>3,92 sehingga disimpulkan terdapat perbedaan kemampuan penyelesaian masalah fisika pada siswa yang belajar dengan strategi open ended bersetting kooperatif dan siswa yang belajar dengan metode konvensional pada kelompok dengan kreativitas tinggi. Tabel 8 menunjukkan bahwa $\mathrm{F}_{\text {hitung }}>\mathrm{F}_{\text {tabel }}$ yaitu 17,24 $>2,76$ maka dapat disimpulkan bahwa kemampuan penyelesaiaan masalah fisika pada siswa yang belajar dengan strategi open ended bersetting kooperatif lebih tinggi dibandingkan siswa yang belajar dengan metode konvensional pada kelompok dengan kreativitas tinggi.
Berdasarkan tabel 7 tampak bahwa $F_{\text {hitung }}$ $>\mathrm{F}_{\text {tabel }}$ yaitu $178,69>4,05$ sehingga dapat disimpulkan terdapat perbedaan kemampuan penyelesaian masalah fisika pada siswa yang belajar dengan strategi open ended bersetting kooperatif dan siswa yang belajar dengan metode konvensional pada kelompok kreativitas rendah. Tabel 8 juga menunjukkan bahwa nilai $\mathrm{F}_{\text {hitung }}>\mathrm{F}_{\text {tabel }}$ yaitu 5,31>2,78 sehingga dapat disimpulkan bahwa kemampuan penyelesaian masalah fisika siswa yang belajar dengan strategi open ended bersetting kooperatif lebih tinggi dibandingkan siswa yang belajar dengan metode konvensional pada kelompok dengan kreativitas tinggi.

Tingkat kreativitas seseorang dapat dipanang sebagai kemampuan seseorang untuk dapat melihat dan menyelesaikan berbagai masalah dari berbagai sudut pandang dan memunculkan berbagai gagasan untuk menyelesaikan permasalahan yang muncul [5]. Setelah mendapatkan pembelajaran dengan strategi open ended bersetting kooperatif dan konvensional. Tampak telihat peningkatan kreativitas dari pada siswa. Hal ini dapat terlihat pada hasil tes akhir. Penerapan strategi pembelajaran Open Ended bersetting kooperatif juga dapat meningkatkan kreativitas Siswa dengan peningkatan skala rendah (mengalami peningkatan 1-2 point), skala sedang (mengalami peningkatan 3-4 point) dan skala tinggi (mengalami peningkatan 5-7 point). Dan peningkatan terbesar berada pada skala sedang yaitu $40 \%$ Siswa. Sedangkan sekitar 33\% mengalami peningkatan pada skala tinggi dan sisanya sekitar $27 \%$ mengalami peningkatan dalam skala rendah. Berdasarkan pada deskripsi tersebut terlihat bahwa strategi open ended bersetting kooperatif dapat meningkatkan kreativitas siswa.

Model kooperatif memungkinkan siswa untuk diberi kesempatan untuk aktif membuat abstraksi sehingga memungkin-kan siswa dapat memunculkan ide-ide sehingga kreativitas siswa 
JIP, Vol.7, No. 1, Edisi Januari 2017, Hal: 1-6 Hena Dian Ayu, Akhmad Jufriadi

dan kemampuan penyelesain masalah akan meningkat [6]. Untuk memunculkan dan meningkatkan kreativitas perlu ada kebebasan berfikir tidak dibawah kontrol dan tekanan [4]. Hasil penelitian serupa oleh Hena juga menunjukkan bahwa ada pengaruh antara pembelajaran dengan strategi open ended bersetting kooperatif dengan tingkat kreativitas [2]. Shimada menjelasakan bahwa terdapat hubungan antara kemampuan pemecahan masalah dengan kemampuan berfikir kreatif, dimana hal ini dapat dikembangkan melalui kebebasan dalam berfikir dengan open ended [9].

\section{KESIMPULAN}

Berdasarkan hasil penelitian dan uji hipotesis yang telah dilakukan, maka kesimpulan dari penelitian ini adalah: 1) kemampuan penyelesaian masalah fisika siswa yang belajar dengan strategi open ended problem bersetting kooperatif lebih tinggi dibandingkan siswa yang belajar dengan pembelajaran konvensional. 2) Terdapat interaksi antara strategi open ended problem bersetting kooperatif dan kreativitas terhadap kemampuan siswa dalam menyelesaikan masalah. 3) kemampuan penye-lesaian masalah fisika pada siswa yang memiliki kreativitas tinggi yang belajar dengan menggunakan strategi open ended problem bersetting kooperatif lebih tinggi dibandingkan dengan siswa yang belajar dengan menggunakan pembelajaran konvensional. 4) Kemampuan penyelesaian masalah fisika siswa dengan kreativitas rendah yang belajar dengan strategi open ended problem bersetting kooperatif lebih rendah daripada pembelajaran konvensional

\section{DAFTAR PUSTAKA}

Dubinsky, E.D. 2007. Using A Theory of Learning in College Couise. (online), http://www.bham.ac.uk/ctimath/th12.htm. diakses tanggal 24 juni 2014.
Hena, D. A. 2013. Peningkatan Kreativitas dan Pemahaman Melalui Strategi Open Ended Bersetting Kooperatif. Jurnal Erudio. Vol 2. No.2

Joyce, B. and Marsha Weil. 1992. Models of Teaching. New Jersey: Prentice Hall.

Khabibah, S. 2006. Pengembangan Model Pembelajaran Matematika Dengan Soal Terbuka Untuk Meningkatkan Kreativitas Siswa Sekolah Dasar. Surabaya: PPS Unesa. Tidak dipublikasikan.

Moll, L. C. 2003. Vygotsky and Education. Instructional Implications and Applications of Sociohistorical Psychology. Cambridge University Press. (online), http:/books.google., diakses 20 November 2013.

Munandar, U. 2007. Mengembangkan Bakat dan Kreativitas Anak Sekola. Jakarta: PT. Gramedia.

Murata, Aki. Fuson, K. (2006). Teaching as Assisting Individual Constructive Paths Within an Interdependent Class Learning Zone: Japaness First Graders Learning to Add Using 10. NCTM: Journal for Research in Mathematics Education, Vol.37 No. 3.

Newman. Claire and Artzt. Alice. (2003). How to Use Cooperative Learning in the Mathematics Class. Reston, NCTM, Virginia.

Shimada,S. \& Becker, J. P 1997. The Open Ended Approach:A New Proposal For Teaching Mathematics, Virginia: National Council of Teacher of Mathematics.

Silver, Edward A. (1997). An Analysis of Arithmetic Problem Posing By Middle School Students. Journal For Research In Mathematics Education, Vol 27. No. 5.

Siswono. 2008. Pengembangan Kretivitas. (online), http:// www.egyankosh.ac.in. diakses 4 April 2014).

Slavin, Robert E. (1994). Cooperative Learning: Theory, Research, and Practice. Second Edition., Allyn and Bacon, Boston.

Suparno, Paul. 1997. Filsafat Konstruktivisme dalam Pendidikan. Yogyakarta: Kanisius. 